\title{
Literatura juvenil e crítica feminista: emancipação nos contos de fadas de Marina Colasanti
}

\author{
Youth literature in the fairy tales by Marina Colasanti \\ Maísa Barbosa da Silva Cordeiro \\ Universidade Estadual do Paraná - UNESPAR - Paranavaí - Paraná - Brasil
}

Rauer Ribeiro Rodrigues

Universidade Estadual de Maringá - UEM - Maringá - Paraná - Brasil

\begin{abstract}
Resumo: Este trabalho analisa a representação de mulheres nos contos "A primeira só" e "São os cabelos das mulheres", presentes nos livros Uma ideia toda azul (1979) e Com certeza tenho amor (2009), de Marina Colasanti. Nosso objetivo é defender que há, nos contos analisados, transgressões de gênero a partir da alteração do papel da mulher nos contos de fadas. Se, majoritariamente, nos contos de fadas, o destino das personagens mulheres é alterada a partir da interferência mágica ou masculina, em Colasanti as próprias mulheres modificam seu destino ao se posicionarem eticamente contra o domínio patriarcal. Os contos analisados apontam para o questionamento, no plano do literário, de valores patriarcais ainda vigentes, por meio de personagens que se debatem com a condição de assujeitamento na qual elas estão imersas..
\end{abstract}

Palavras-chave: Crítica literária feminista; Estudos de gênero; Narrativas primordiais.

Resumen: This paper analyzes the representation of women in the fairy tale "A primeira só" and "São os cabelos das mulheres", presente in the books Uma ideia toda azul (1979) and Com certeza tenho amor (2009), by Marina Colasanti. Our objective is to defend that, in the narratives analyzed, there are gender transgressions based on the alteration of the role of women in fairy tales. If, mainly, in fairy tales, the fate of the female characters is altered by magical or male interference, in Colasanti the women themselves modify their destiny by positioning themselves ethically against patriarchal rule.The fairy tales analyzed question, at the literary level, the patriarchal values still in force, through characters who are faced with the condition of subjection in which they are.

Keywords: Feminist literary criticism; Gender studies; Primordial narratives.. 


\section{Introdução}

Os contos de fadas ${ }^{1}$ analisados neste trabalho, "A primeira só", de Uma ideia toda azul (2015 [1979]) e "São os cabelos das mulheres", de Com certeza tenho amor (2015 [2009]), têm como protagonistas mulheres em confronto com 0 ideal social sobre a figura feminina. Um e outro elucidam a trajetória de protagonistas que, ao se verem defrontadas pelos valores patriarcais que regem a sociedade na qual estão inseridas, precisam atuar e tomar decisões para que a situação problemática que as envolve seja solucionada se solucione. Publicados com trinta e um anos de diferença, evidenciam temáticas recorrentes na escrita de Colasanti: a mulher e o feminino. As temáticas que deslindam os contos estão, ainda, relacionadas a outra, que parece ser a central da contística e Marina Colasanti: a fragmentação dos sujeitos em um tempo em que já não é mais possível escrever contos de fadas partindo-se do dualismo das figuras do bem e do mal, o que é comum nos contos tradicionais.

Marina Colasanti nasceu em Asmara, capital da Eritreia, em 1937. Veio para o Brasil, com a família, em 1948, onde ficou. Artista plástica de formação, ela atuou no jornalismo e também em publicidade. Marina, em sua carreira, traduziu diversas obras da literatura universal. Como escritora, lançou mais de cinquenta títulos, sendo que o primeiro foi publicado em 1968. Ao voltar-se para a literatura, pôde, também, voltar-se às artes plásticas novamente, pois se tornou sua própria ilustradora. Sua obra é bastante premiada. Entre seus prêmios estão Jabutis, Grande Prêmio de Crítica da APCA, Biblioteca Nacional para poesia, Portugal Telecom de Literatura $2011^{2}$. Ainda se tornou horsconcours da Fundação Nacional do Livro Infantil e Juvenil (FNLIJ), após ter sido várias vezes premiada. Uma ideia toda azul foi premiado, em 1980, na categoria Jovem, e Para sempre tenho amor foi premiado, em 2010, na categoria Jovem HorsConcours, ambos pela FNLIJ.

Desde seus primeiros contos, Colasanti promove importantes rupturas em relação à estrutura tradicional dos contos de fadas. Seu interesse pelo maravilhoso decorre de considerar que o inconsciente humano tem se mantido inalterado ao longo do tempo, pois, para ela, "[...] muda a realidade externa, mas a nossa realidade interior, feita de medos e fantasias, se mantém inalterada. E é com esta que dialogam as fadas, interagindo simbolicamente, em qualquer idade e em todos os tempos" (COLASANTI, 2014, s.p.). Ao mesmo tempo, realiza alterações, também, nos modos de representação das personagens, que não pertencem mais às categorias dos heróis e dos antagonistas, mas são sujeitos atuando na resolução de seus conflitos com erros e acertos.

Colasanti tem, ainda, importantes publicações não ficcionais acerca da condição da mulher. Destacamos, aqui, as que ela publica em 1980, como Uma nova mulher e Mulher daqui pra frente. Assinalamos as duas publicações pela época em que foram escritas, já que foi nesse momento, como defende Heloisa Buarque de Hollanda (1994) em Tendências e impasses: o feminismo como crítico da cultura, que o feminismo surgiu como uma importante categoria crítica e política. A década de 1980 , aliás, foi fundamental para o fortalecimento da crítica feminista, bem como da institucionalização acadêmica dessa crítica. A crítica literária feminista, por sua vez, favoreceu maior participação das mulheres na escrita literária, mas, também, a revisão da historiografia literária, por meio de um esforço de inúmeras pesquisadoras desde então.

É proposta deste trabalho, então, analisar "A primeira só" e "São os cabelos das mulheres" de modo a auscultar, na tessitura de Marina Colasanti, tanto as rupturas promovidas em relação aos contos de fadas tradicionais, quanto à renovação dos modos de representação das protagonistas mulheres. Ao concordar com Teresa de Lauretis (1994), que defende que a o lugar de representação é, além de lugar para reprodução, lugar potencial para mudanças desejadas, elucidamos a importância de entender em que medida a literatura apresenta personagens em processo de desconstrução dos valores patriarcais, e se eventualmente aponta para as mudanças desejadas no que tange aos papéis sociais de gênero. Por se tratar de contos premiados na categoria jovem, entende-se que tais obras alcançarão leitores em 
processo de construção de suas subjetividades, e, nesse sentido, contribuirão para a formação de sujeitos mais críticos em relação às questões de gênero. Entendemos que os contos de fadas o contato íntimo com o sagrado partilhado nos mitos, reescrevendo o arquétipo invocado pelas narrativas em uma outra clave.

\section{Estrutura e personagem do contos de fadas}

Dentre o grande número de narrativas que tratam da problemática do ser humano em relação a si próprio e ao meio social no qual se insere, estão os contos de fadas, originários de histórias que antes eram destinadas também a adultos, mas que, com o advento da imprensa, foram aprimorados e ganharam uma estética literária. Foram Charles Perrault, com Contos da mãe Gansa, MMe. D'Aulnoy, com Contos de fadas, e Fénelon, com Telêmaco, no final do século $\mathrm{XVII}$, os pioneiros em transformar narrativas populares prenhes de simbologia e de experiências humanas em literatura com acabamento estético que permitisse identificar esses contos como produções destinadas à infância, à época, uma distinção emergente.

Bruno Bettelheim (1980), psicanalista, encontrou nos contos de fadas uma maneira de contribuir com o amadurecimento psicológico de crianças gravemente perturbadas, considera que "[p]ara não ficar à mercê dos acasos da vida, devemos desenvolver nossos recursos interiores, de modo que nossas emoções, imaginação e intelecto se ajudem e se enriqueçam mutuamente" (BETTELHEIM, 1980, p. 12). Com o propósito de auxiliar as crianças a entenderem a si mesmas, Bettelheim (1980) fomentava, junto a elas, a leitura de contos de fadas, pois acredita que os contos de fadas contribuem para o entendimento da criança sobre si própria.

Além do psicanalista, Nelly Novaes Coelho (1987), crítica literária, defende os contos de fadas e sua relação com a formação do ser humano. Para a autora, os contos de fadas contribuem para que a criança vislumbre formas de solução de problemáticas inerentes à existência humana que a possibilita entender que, para a resolução de conflitos internos, será necessário um embate que a levará ao alcance de um estado diferente do estado anterior, no qual se encontrava, ou seja, haverá um amadurecimento.

Os contos de fadas têm estreita relação com a necessidade humana de cambiar experiências. São eles que aconselham e mostram às crianças as primeiras histórias acerca de desafios, vitórias, ganhos, medos e a relação humana com o que lhes é desconhecido. Imerso em um ambiente marcado pelo insólito, os contos de fadas despertam grande atração das crianças. Para Walter Benjamin, o conto de fadas:

[...] é ainda hoje o primeiro conselheiro das crianças, porque foi o primeiro da humanidade, e sobrevive, secretamente, na narrativa. O primeiro narrador verdadeiro é e continua sendo o narrador de contos de fadas. Esse conto sabia dar um bom conselho, quando ele era difícil de obter, e oferecer sua ajuda, em caso de emergência. Era a emergência provocada pelo mito. $O$ conto de fadas nos revela as primeiras medidas tomadas pela humanidade para libertarse do pesadelo mítico. (BENJAMIM, 1994, p. 215).)

O conto de fadas, como se nota, tem por função o aconselhamento, e mostra à criança experiências advindas do comportamento humano frente ao desconhecido. Ao dispor de personagens em conflito, que passarão por adversidades até conquistar o prêmio final, eles mostram que há sempre um caminho a ser traçado, independentemente de qual seja a problemática que se apresenta.

\section{A renovação dos contos de fadas de} Marina Colasanti

Nos contos de Marina Colasanti, o aconselhamento é significativamente alterado, pois ele conduz o leitor mais a questionar suas próprias experiências do que alterar um comportamento não desejado, como no caso de "Chapeuzinho Vermelho", que aprende a não desviar do caminho, ou mais fortalecido, como em "João e o pé de feijão", que consegue o sustento para a família ao enfrentar 0 gigante.

Assim, os contos alteram-se no que tange às formas de aconselhamento, até mesmo por que, como aponta Benjamin, a experiência de narrar está em vias 
de extinção: é "[...] como se estivéssemos privados de uma faculdade que nos parecia segura e inalienável: a faculdade de intercambiar experiências" (BENJAMIN, 1994, p. 197). Os heróis inquestionáveis e essencialmente bons dos contos de fadas tradicionais dão lugar a sujeitos que se equilibram entre vivências felizes e tristes; entre qualidades e defeitos. Entram em cena, enfim, personagens com características humanas. A alteração na forma de intercambiar experiências é visível nas narrativas de Colasanti, visto que, ao contrário da maior parte dos contos de fadas recolhidos da tradição oral, Marina Colasanti aborda a transformação do próprio sujeito. As protagonistas modificam a si próprio ao longo da narrativa a partir de uma ação própria e, quando altera sua relação consigo próprio, altera também sua relação com o que lhe é alheio.

Um dos aspectos nos quais Colasanti altera seus contos parece dizer respeito aos leitores aos quais se destina. Devido à ampliação das temáticas, a ausência de um final especialmente feliz, acompanhado de uma moral, bem como a utilização de uma linguagem mais elaborada, simbólica e poética faz com que os contos não alcancem somente os pequenos leitores. Atesta essa distinção o fato de que os livros nos quais os contos aqui analisados foram premiados na categoria Jovem da FNLIJ.

Em Colasanti, entre os aspectos do maravilhoso, está, como mostra Nilda Medeiros (2009), a abordagem em relação ao longe:

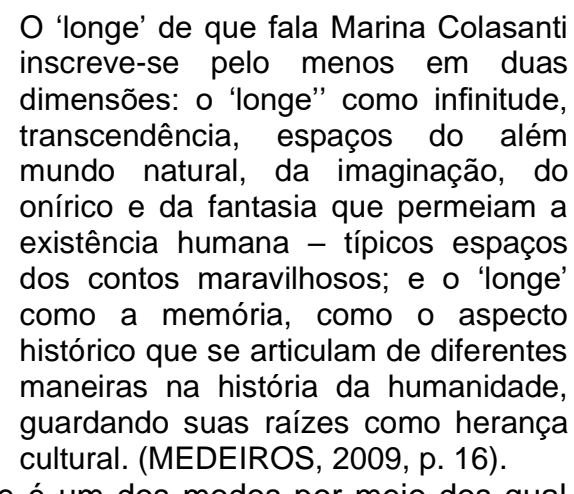

O longe é um dos modos por meio dos qual

Colasanti circunscreve o maravilhoso em sua produção. Não é possível, assim como não é possível nos contos de fadas tradicionais, localizar em qual data, ou mesmo em qual momento histórico se situa a narrativa. É possível saber, somente, que foi no passado. Do mesmo modo, as descrições do local são abstratas: as narrativas se desenrolam em uma aldeia, ou uma floresta, ou em um reino antigo. A ausência de uma delimitação precisa de tempo e espaço conduz o leitor para um tempo e um local distantes, mas imprecisos: há, então, o espaço para a imaginação e construções individuais, tão caras ao conto maravilhoso .

A distância temporal, contudo, é demarcada de forma distinta dos contos de fada tradicionais, que recorrem a fórmulas como "era uma vez", ou "em um reino distante". Marina Colasanti demarca essa distância por meio da utilização do pretérito perfeito do indicativo: "Era linda, era filha, era única. Filha de rei" (COLASANTI, 2015, p. 29), em "A primeira só", ou "Naquela aldeia de montanha perdida entre neblinas, a chuva havia começado há mais tempo do que era possível lembrar" (COLASANTI, 2015, p. 247), de "São os cabelos das mulheres". Ao não recorrer às fórmulas tradicionais, o gênero se renova no que diz respeito ao modo de narrar, mesmo que a utilização dos verbos também indique um pretérito não demarcado.

Se os elementos dêiticos iniciais, mencionados anteriormente, são o que aproximam, entre outros aspectos, as narrativas de Colasanti do modo maravilhoso, a ausência de um final feliz é o que os distancia. É possível notar, em Colasanti (2015), a ausência de um final feliz, característica muito presente nos contos resgatados da tradição oral, e destinados ao público infantil. Há, ainda, a ausência de delimitação de uma figura boa ou uma figura ruim na narrativa. Como aponta Bettelheim (1980), em contos de fadas, a presença do maniqueísmo possibilita que a criança vislumbre, mais facilmente, que sentimentos de raiva e de afeto podem estar presentes no mesmo ser humano. Ao inserir, contudo, personagens inteiramente bons contra personagens inteiramente maus, o conto de fadas possibilita a assimilação da dualidade humana por um indivíduo que não tem maturidade para compreender tais conflitos:

Enquanto ouve o conto de fadas, a criança forma ideias sobre o modo de ordenar o caos que é sua vida interna. O conto de fadas sugere não só isolar e separar os aspectos díspares e confusos da experiência da criança em pólos opostos, mas também projetá-los 
em diferentes figuras. (BETTELHEIM, 1980 , p. 96)

Os contos de fadas destinados a crianças pequenas, portanto, expõem precisamente as figuras do bem e do mal de forma bastante direta e categórica, permitindo à criança apreender o aspecto central do problema, o que, pela questão da idade, teria dificuldade em fazer em uma narrativa mais complexa. Lidam, majoritariamente, como defende Bettelheim (1980), com personagens tipos.

Por encenarem personagens que apresentam pouco conflito pessoal, fazem com que a assimilação dos conflitos humanos seja mais fácil para as crianças. Ao vivenciarem pelas narrativas a existência de comportamentos bons e ruins nas personagens, a criança percebe, aos poucos, que tais conflitos são inerentes à existência humana. Contudo, conforme a criança cresce, ela adquire condições de compreender a complexidade da natureza humana. Os conflitos, que eram percebidos individualmente, de personagem para personagem, passam, então, a habitar a mesma personagem. À medida que as ficções apresentadas aos sujeitos vão se tornando mais complexas, a criança percebe como é complexa a natureza do ser humano.

Certamente, muitos contos de fadas tradicionais ainda respondem aos anseios dos leitores contemporâneos, e os oferecem possibilidades de desenvolvimento de sua autonomia e de sua liberdade. A produção de contos de fadas contemporânea permite vislumbrarmos que o gênero não é estático. Um exemplo dessa alteração são as formas de representação do bem e do mal. Ao sobreviverem, na contemporaneidade, vemos que os contos de fadas mantêm viva a produção do mito, ou seja, das narrativas primordiais sobre o início ou o fim das coisas, mas, ao serem alterados, é importante perceber que "[n]ão é a mera sobrevivência do bem que se reflete nos contos de fadas contemporâneos, mas a projeção fantástica das possibilidades para condições de vida não alienantes" (ZIPES, 2009, p. 170-171, tradução nossa ).

Em Colasanti, os contos também apresentam um dilema existencial. Diferentemente dos contos tradicionais, contudo, não há a apresentação de personagens bons ou ruins. O que norteia as narrativas é a existência de um problema existencial a ser solucionado, como em "A primeira só", ou um problema social, como em "São os cabelos das mulheres".

É justamente a busca pela solução de tal dilema que irá delinear a narrativa. A vitória depende do enfrentamento, por parte do protagonista, do dilema a ele imposto. A vitória somente é alcançada no momento em que ele se defronta com a necessidade de agir em relação às dificuldades. Do mesmo modo, Colasanti (2015) não expressa a necessidade de premiar ou castigar personagens, assim, a narrativa chega ao final quando o conflito é, de fato, solucionado, e não quando o mal é finalmente vencido.

Outra alteração bastante significativa na contística de Colasanti diz respeito ao modo de representação das personagens mulheres, que se desvinculam da representação dos contos de fadas tradicionais, nos quais aparecem silenciadas, ou à espera de um príncipe salvador. Elaborados em um momento em que o discurso feminista ainda era inexistente, os contos de fadas parecem atender, muitas vezes, aos anseios de leitores de um momento histórico em que as relações de gênero ainda não eram uma questão a ser considerada. Alia-se a esse aspecto 0 fato de que a produção literária, especialmente nesse gênero, é inaugurada exclusivamente por meio de vozes masculinas.

Os debates acerca da condição feminina têm ganhado, contemporaneamente, bastante força. A crítica literária feminista está bastante fortalecida e com um número crescente de pesquisadoras(es) que buscam investigar, tanto em uma perspectiva sincrônica quanto diacrônica, o papel ideológico atribuído à mulher. Para tanto, é fundamental refletir as formas de representação da mulher nos contos de fadas, tendo em vista que foram cunhados em épocas anteriores às revoluções feministas e ainda estavam imersos em uma cultura que dificultava a existência de personagens mulheres independentes.

Para Luisa Passerini (1986), um aspecto a ser observado na produção literária sobre a mulher é que "[...] as moças e as mulheres muitas vezes estão 
ausentes ou mudas" (PASSERINI, 1986, p. 363). A autora destaca o quanto há a carência, em diversas publicações, da presença das mulheres, e, principalmente, da voz das mulheres, enunciando sobre si próprias.

A crítica feminista, ao se debruçar sobre os contos de fadas, permite que sejam questionados os modos de representação das mulheres nesse gênero, bem como denunciam a necessidade masculina de expor a feminilidade da mulher ao caracterizá-la por meio de seus atributos físicos, de sua bondade e de sua caridade. Essa crítica, contudo, também permite que se vislumbrem outras formas de representação que não sejam, somente, as que possuem uma voz de autoridade masculina que permeia as relações de gênero presentes nas narrativas maravilhosas. Ao se debruçar sobre a produção contemporânea, por exemplo, deixa entrever produções com um discurso não arraigado do poder masculino, ou da subserviência da mulher, e denotam a existência de mulheres ativas, questionadoras e que confrontam relações de poder entre homens e mulheres. Além disso, tais contos de fadas distanciam a realidade da mulher de um campo semântico já bastante conhecido dos contos de fadas: casamento, marido, amor e felicidade (a partir do casamento). As produções literárias contemporâneas destinadas aos jovens leitores deixam entrever que a realidade da mulher não está vinculada exclusivamente a esses temas. Essa não é, contudo, uma questão tão simples, especialmente se pensarmos que, hoje, crianças e adolescentes crescem em uma via de mão dupla, já que as mulheres estão presas entre a necessidade de preservar valores e a necessidade de acompanhar o movimento feminista, em expansão.

As modificações propostas por Colasanti nos contos de fadas de sua autoria não são exclusividade da autora. Desde a segunda Guerra Mundial, os contos de fadas vêm sendo modificados consideravelmente devido a uma gama de motivos: "Os contos de fadas não são apenas considerados sexistas, racistas e permeados pelo autoritarismo, mas, em geral, refletem um contexto de uma sociedade semifeudal e patriarcal" (ZIPES, 2009, p. 1970, tradução nossa ). Desse modo, os aconselhamentos e as experiências transmitidas pelos contos de fadas tradicionais nem sempre correspondem a anseios do leitor nascido em outro contexto social, tecnológico e cultural.

Colhidos da tradição oral, os contos de fadas tradicionais dialogam com um contexto social marcado por outras características; porém, o século $X X$ e as alterações que ele promoveu não permitem que a produção, ou mesmo o estudo crítico dos contos de fadas, desconsiderem uma série de mudanças sociais. Para Zipes (2009), tais mudanças, especialmente a partir da década de 1960, "[...] foram marcadas por movimentos por direitos civis, protestos antiguerras, pelo crescimento do feminismo, e demandas por autonomia por parte de grupos minoritários e pequenas nações com privações em todo o mundo" (ZIPES, 2009, p. 171, tradução nossa ). Dentro dessa perspectiva, os contos de fadas de Marina Colasanti, ao não reproduzirem a utopia típica dos contos de fadas, marca-se como socialmente elaborados em um novo contexto, e para leitores com anseios e problemáticas diferentes, e imersos em uma estrutura social significativamente distinta, que almeja, cada vez mais, estar liberta do autoritarismo.

\section{O protagonismo da mulher em "A primeira só" e "São cabelos das mulheres"}

A crítica literária feminista vem se ocupando, nas últimas décadas, da denúncia das várias formas de violência representadas na literatura. Do mesmo modo, investiga as estratégias discursivas por meio das quais as personagens enfrentam o poder do patriarcado, rompem com o machismo e elaboram a si próprias de maneira mais autônoma. Carol Hanish (1969), em artigo intitulado "O pessoal é político", contribui para assentar o que seria uma das principais características da segunda onda do feminismo: defender que as violências sofridas pelas mulheres no espaço doméstico eram representativas de assimetrias para além do plano subjetivo. As narrativas aqui analisadas são importantes para compreender a relação entre o pessoal e o político: as personagens alteram seu entorno quando se posicionam. 
"A primeira só" conta a história de uma princesa-menina, que, muito triste e solitária, passa os dias isolada no castelo, sem ter com quem brincar. Preocupado com a solidão da filha, o rei resolve dar a ela um grande espelho. Ela, por sua vez, enxerga no espelho uma amiga, e não sua própria sombra. Com a presença de um narrador onisciente, a história culmina com a menina sozinha novamente, após quebrar o espelho com uma bola de ouro e, na sequência, se atirar no lago, devido à solidão novamente experimentada e à falta da amiga que viu no espelho. Há somente dois personagens na narrativa: o pai e a filha.

"São os cabelos das mulheres" narra os problemas de uma aldeia que sofre devido ao excesso de chuva. Buscando respostas, os velhos sábios, responsáveis pelas decisões por toda a aldeia decidem que o problema é causado pelos cabelos das mulheres, e, então, mandam cortá-los. Cessaram as chuvas, mas a aldeia foi tomada por serpentes. Novamente, julgaram culpados os cabelos das mulheres. Após encontrar uma única menina ainda com cabelos, a sua mãe, em posse de uma agulha, começou a costurar a boca das serpentes uma a uma. Pairou, então, sobre a aldeia, um frio intenso. Ao não encontrar soluções, bastou o tempo para fazer crescer os cabelos. Cessou-se, enfim, o frio, logo que todas se livraram do xale que os cobriam. O narrador também é onisciente e há destaque somente para as personagens que atuam, de fato, na diegese, a mãe e a filha. Os outros personagens são descritos somente por seu grupo social: os velhos sábios, os homens, as mulheres e as crianças.

$\mathrm{Na}$ estrutura dos dois contos, verificamos, entre as motivações para a ação, de acordo com Morfologia do conto maravilhoso, de Vladimir Propp (1984), a falta, a ausência de algo desejado pelo protagonista, que buscará tentar conquistar o que the falta. No caso dos contos de Marina Colasanti aqui analisados, há, justamente, a falta de algo desejado pelas protagonistas, que são, no caso de "A primeira só", uma amiga para brincar, e no caso de "São os cabelos das mulheres", a chuva, já que a seca está castigando os moradores da aldeia. Diferentemente dos contos de fadas tradicionais, contudo, quem promove a busca não são as protagonistas, em um momento inicial, mas os patriarcas que tentam, por sua vez, solucionar, em um primeiro momento, a adversidade.

"A primeira só" tem, no início de sua diegese, uma princesa que chora ao longo dos dias devido à solidão que vivencia, pois não tem ninguém para brincar:

Era linda, era filha, era única. Filha de rei. Mas de que adiantava ser princesa se não tinha com quem brincar? Sozinha, no palácio, chorava e chorava. Não queria saber de bonecas, não queria saber de brinquedos. Queria uma amiga para gostar. (COLASANTI, 2015, p. 29).

A repetição do verbo "era" contribui para acentuar a expressão de um tempo passado, ou do longe, como já acentuamos, recorrendo a Medeiros (2009). De sua solidão, surge o anseio por uma amiga. A figura do pai aparece quando, entristecido pela solidão da filha, decide construir um grande espelho no quarto dela para que ela tenha, finalmente, com quem brincar:

De noite o rei ouvia os soluços da filha. De que adiantava a coroa se a filha da gente chora à noite? Decidiu acabar com tanta tristeza. Chamou o vidraceiro, chamou o moldureiro. E em segredo mandou fazer o maior espelho do reino. E em silêncio mandou colocar o espelho ao pé da cama da filha que dormia. (COLASANTI, 2015, p. 29).

A voz do pai aparece, no início, de modo mais impetuoso em relação à voz da filha: os verbos, quando associados a ela, estão no passado contínuo, o que deixa a impressão de um tempo que se arrasta. Já quando o pai toma a decisão de presenteá-la com o espelho, os verbos se modificam e são conjugados no pretérito perfeito, não deixando dúvidas das ações da personagem:

Quando a princesa acordou,
já não estava sozinha. Uma
menina linda e única olhava
para ela, os cabelos ainda
desfeitos do sono. Rápido
saltaram as duas da cama.
Rápido chegaram perto e
ficaram se encontrando.
Uma sorriu e deu bom dia. A
outra deu bom dia sorrindo.
- Engraçado - pensou uma
-, a outra é canhota.
E riram as duas.
(COLASANTI, 2015, p. 29).

Quando a princesa acordou, já não estava sozinha. Uma menina linda e única olhava para ela, os cabelos ainda Rápido chegaram perto e ficaram se encontrando. Uma sorriu e deu bom dia. A outra deu bom dia sorrindo.

- Engraçado - pensou uma (COLASANTI, 2015, p. 29). 
A cena que aparece na sequência evidencia a personagem feliz com a presença da nova amiga, e é possível recorrer ao mito de Narciso: a amiga da qual se encanta não é ninguém além de si própria. A menina não percebe que não se trata de outra pessoa, e imediatamente se encanta com a nova presença em seu quarto e se põe a brincar com a amiga. A decisão tomada pelo rei, de presentear a filha com uma amiga, tem o resultado esperado, de tal forma que o rei providencia outros brinquedos à filha: "O rei, encantado com tanta alegria, mandou fazer brinquedos novos, que entregou à filha numa cesta" (COLASANTI, 2015, p. 29).

Além disso, pensar a condição da mulher perpassa pela ressignificação das relações entre homens e mulheres, permeada pela dominação e sujeição:

Toda relação de dominação, entre dois grupos ou duas classes de indivíduos, impõe limites, sujeição e servidão àquele(a) que se submete. Ela introduz uma dissimetria estrutural que é, simultaneamente, o efeito e o alicerce da dominação: um se apresenta como representante da totalidade e o único depositário de valores e normas sociais impostas como universais porque os do outro são explicitamente designados como particularidades. [...] A dissimetria constituinte da relação de dominação aparece não somente nas práticas sociais, mas também no campo da consciência e até nas estratégias de identidade. (APFELBAUM, 2009, p. 76).

Como esclarece Apfelbaum (2009), as

relações de dominação entre dois grupos, no caso, entre homens e mulheres, provoca impacto não somente nas práticas sociais, mas, também, em como o próprio sujeito constrói a sua identidade. É comum homens se perceberem, por exemplo, como emocionalmente mais fortes e mulheres se verem como mais frágeis e sentimentais.

Observando a relação entre pai e filha presente no conto, percebe-se a necessidade do pai de interferir no problema da filha, e solucioná-lo, ele próprio. Nota-se que as decisões que ele toma não são tomadas com base em um diálogo com a menina, mas, sim, a partir do que ele considera mais adequado.

Após a construção do espelho, e felicidade momentânea da princesa, o rei a presenteia com muitos brinquedos para ela brincar com a nova amiga, fruto de seu reflexo. Entre os novos brinquedos, contudo, está uma bola de ouro com a qual a princesa quebra o espelho. Ao jogá-la para a amiga, o resultado não poderia ser outro: o espelho se transforma em pedaços. Dali, porém, surgem outras amigas, pois o espelho, antes um, agora, estilhaçado, reflete diversas amigas, das quais a princesa vai se cansando rapidamente, e quebrando o espelho para obter novas amigas, de tal forma que logo resta somente pó:sociedade brasileira não se constituía um verdadeiro da época.

Sobre o poder institucionalizado da polícia, verificamos enunciados de resistência à violência propalada na favela. Vale ressaltar que, nestes enunciados, muitas vezes, há a "vigilância e a punição" institucionalizada e não institucionalizada

Por fim, no campo do exercício do poder, embora o título do diário sugira apenas uma luta de classes, vemos que no desenrolar do relato há constante relações de forças discursivas. Dito de outro modo, a escrita que resiste ao poder em sua rede e a escrita que resiste enquanto poder, já que no diário, há enunciados que evidenciam como vai sendo tecida esta teia. Neste sentido, abordar as questões para compreender as relações de força do discurso, que têm mecanismos de interdição externo e interno, evidenciam que onde há poder há resistência.

Mas duas eram menores do que uma, quatro menores do que duas, oito menores do que quatro, doze menores do que oito.

Menores cada vez menores. Tão menores que não cabiam em si, pedaços de amigas com as quais não se podia brincar. Um olho, um sorriso, um pedaço de si. Depois, nem isso, pó brilhante de amigas espalhado pelo chão. (COLASANTI, 2015, p. 30).

Sozinha novamente, pois sem o espelho não tinha amigas, a princesa se desespera de tal modo que corre pelo jardim até chegar ao lago. Ao contemplá-lo, tem uma surpresa - reencontra a amiga, que é na verdade, ela própria, já que se trata de um reconhecimento narcísico de sua imagem, na qual a personagem projeta um reflexo de si:

No reflexo da água a amiga esperava por ela. Mas a princesa não queria mais uma única amiga, queria tantas, queria todas, aquelas 
que tinha tido e as novas que encontraria. Soprou na água. A amiga encrespou-se, mas continuou sendo uma. Então a linda filha do rei atirou-se na água de braços abertos, estilhaçando o espelho em tantos cacos, tantas amigas que foram afundando com ela, sumindo nas pequenas ondas com que o lago arrumava sua superfície. (COLASANTI, 2015, p. 30).

A diegese culmina com a morte da princesa em busca de suas amigas perdidas. Aqui, o verbo marca, agora, a ação da princesa: ao tomar a decisão de se atirar no lago em busca das amigas, o verbo também é o pretérito perfeito, marcando, então, a ação da princesa. A menina encerra a sua trajetória sozinha, sem a interferência do pai, pois, agora, havia encerrado seu ciclo de solidão, ao buscar a imagem tão desejada, as tantas amigas que eram reflexos de si, pois ela já não concebe uma vida em que não esteja cercada de seu reflexo.

Já "São os cabelos das mulheres" inicia-se exatamente como os contos de fadas tradicionais: descrevendo um local inexato e em um tempo impreciso. Do mesmo modo, apresenta, logo no início, a problemática que norteará a narrativa:

Naquela aldeia de montanha perdida entre neblinas, a chuva havia começado há mais tempo do que era possível lembrar. Só água vinha do céu, em fios tão cerrados que as nuvens pareciam cerzidas ao chão. As plantações haviam-se transformado em charcos, as roupas já não secavam junto aos fogos fumacentos, e pouco ou nada restava para comer. (COLASANTI, 2015, p. 247).

A história tem seu início marcado com a presença de uma forte chuva há vários dias. Devido ao tempo em que se prolonga, já não há plantações e a comida também está restrita. Sem saber o que fazer, os aldeões recorreram aos velhos sábios da aldeia para buscar uma solução: "Reuniram-se os velhos sábios em busca de uma resposta, e longamente deliberaram estudando as antigas tradições. - São os cabelos das mulheres - disseram por fim. $E$ obedecendo aos pergaminhos, ordenaram que fossem cortados" (COLASANTI, 2015, p. 247). Ressalta-se a busca da solução por meio dos saberes antigos, concentrados nas figuras dos velhos sábios, para solucionar a problemática apresentada aos aldeões. Também se nota que não há uma justificativa apresentada para a decisão. Ao concluir que o problema são os cabelos das mulheres, eles simplesmente são cortados. Do mesmo modo que o conto anteriormente apresentado, este, também apresenta a voz patriarcal de modo bastante imperativo.

A escolha do cabelo enquanto um problema, contudo, não é aleatória. É comum encontrar associações dos cabelos das mulheres consideradas bruxas, na época medieval, com o Diabo:

O toque, o olhar ou a voz de uma
bruxa podem enfeitiçar o juiz; deve-se
proceder a uma raspagem de cabelos
e pêlos pubianos, pois as servas de
Satã costumam ali manterem
escondidos talismãs e sinais
demoníacos, mas mesmo sem
qualquer instrumento podem se
manter caladas pela inspiração do
Diabo. (LIEBEL, 2004, p. 48).

Ou como mostra Silvia Federici (2004), sobre as pecadoras:

$\mathrm{Na}$ Inglaterra, eram marcadas na testa com ferros quentes de maneira semelhante à 'marca do Diabo', e depois eram chicoteadas e tinham seus cabelos raspados como bruxas - o cabelo era visto como o lugar favorito do diabo. (FEDERICI, 2004, p. 391).

Nas duas citações, é perceptível a demonização sofrida pelos cabelos femininos. Era bastante comum a atitude de raspar a cabeça das mulheres consideradas bruxas, devido ao forte poder a ele atribuído. Parece vir dessa crença a associação feita, no conto, dos problemas naturais enfrentados na aldeia com os cabelos das mulheres, pois faz parte de uma associação história com o pecado, com o mal, ou diretamente com o Diabo.

Em um episódio semelhante o das conhecidas caça às bruxas medieval, o episódio em que se cumpre com a ordem dos velhos sábios é realizado na praça da aldeia, em um evento ritualístico no qual todos estão presentes, e se enchem de esperança:

Na praça da aldeia, desfeitas tranças e coques, soltos todos os grampos, os longos fios que chegavam à cintura foram decepados rente à raiz, e entregues à chuva. Todos os viram descer na correnteza, ondulantes e negros. Todos se encheram de 
esperança, enquanto as mulheres abaixavam a cabeça deixando a água escorrer em filetes sobre a pele nua. (COLASANTI, 2015, p. 247).

O corte dos cabelos tem efeito inicial positivo. As chuvas cessam, e todos se veem livres do problema. Assim como em "A primeira só" a decisão patriarcal gera um efeito imediato, porém, esse efeito vai esvaindo-se conforme se percebe que, novamente, o conflito retornará, mesmo que transfigurado.

Então, como o efeito positivo não é duradouro, logo que o sol começa a aquecer a aldeia, ela é tomada por grandes serpentes: "Vindas daquele calor, talvez, daqueles vapores abafados no escuro silêncio, longas serpentes negras começaram a deslizar para a luz" (COLASANTI, 2015, p. 248). Surgindo sem que os moradores saibam de onde, as serpentes tomam a vila, deixando-os sem ação. Novamente, contudo, vão buscar respostas nos saberes transmitidos pelos velhos sábios. Dessa vez, os saberes já estão imbricados nas vozes dos aldeões, que não mais precisam recorrer aos velhos sábios. Eles mesmos chegam à conclusão de que o problema é causado pelos cabelos das mulheres:

- São os cabelos das mulheres! -
exclamaram afinal os aldeões sem
necessidade de reunir os sábios. E as
mulheres riram, escondendo o rosto nos
lenços e nos xales com que cobriam
suas cabeças. - Acabem com isso! -
ordenaram-lhes os sábios. E não se
referiam ao riso, mas às serpentes. E
com voz que não admitia réplica,
repetiram - Acabem com isso,
mulheres! (COLASANTI, 2015, p. 248).

Ao se verem, contudo, sem os cabelos, elas questionam, pela primeira vez, a possibilidade de solucionarem o problema. Procuraram e encontraram uma única menina que ainda tinha mantido os cabelos, por ter sido confundida com um menino. Agora, contudo, não são os homens que decidem como a problemática será solucionada:

Desatado o cordão que prendia o rabicho, os cabelos desceram cobrindo as orelhas. A mãe colheu um fio, enfioo numa agulha. Todos olhavam. Todos viram a mãe levantar uma pedra, suspender a serpente que ali se abrigava e, com pontos firmes, coserIhe a boca. Todos viram a serpente afastar-se deslizando ladeira abaixo. $O$ rabicho da menina já era apenas um fio quando a última ondulação negra desceu a encosta e a grama fechou-se sobre o seu rastro. (COLASANTI, 2015, p. 249).

O final que encerra o conto é eufórico, feliz, quando comparado ao final de "A primeira só". Ele marca, de forma mais incisiva, o posicionamento da mulher para que se alcance uma solução para uma problemática de todos. Como as mulheres se apresentaram resistentes em relação às ordens advindas dos saberes dos anciões, conseguiram certa mudança de perspectiva em relação ao grupo, como se pode notar nos parágrafos que encerram a diegese:

Ainda fazia frio na manhã em que a primeira mulher tirou o xale. Sacudiu a cabeça. Os cabelos que haviam crescido rodearam-lhe o rosto. E porque aquela havia tirado o xale, uma e logo outra a imitaram, uma quarta desfez sobre a testa o nó que prendia o lenço, cabeças de mulheres assomaram às janelas, descobertas. Os cabelos, lisos, crespos, ondulados, dançavam livres farfalhando como folhas, cintilaram ao sol que de repente não parecia tão pálido. Em algum ponto daquela manhã, a primavera pôs-se a caminho. - São os cabelos das mulheres disseram os homens farejando $o$ ar que se fazia mais fino.

E sorriram. (COLASANTI, 2015, p. 249).

O segundo conto aqui analisado aponta de forma mais incisiva para a importância de um posicionamento da mulher, bem como o impacto da ação de uma mulher em relação às próximas. Percebese que, quando uma se desprende do xale, e, com ele, da imposição vislumbrada ao longo da narrativa sobre o cabelo da mulher, as outras a copiam.

Como defendemos, os contos de Colasanti rompem com a estrutura tradicional por dois motivos centrais: o primeiro é o final feliz. Em nenhum dos dois há um final feliz, especialmente, o primeiro, que culmina com a morte da protagonista. $O$ que predomina é uma espécie de busca para a solução de uma angústia: o ponto em que as narrativas culminam é quando se encontra uma resposta, por meio da própria personagem, para o problema enfrentado. Há, contudo, interferência de um universo mágico. Essa interferência é aceita pelas personagens: em "A primeira só" a protagonista vê a sua própria imagem no espelho e ali enxerga uma amiga e não está mais sozinha; em "São os cabelos das mulheres" a 
personagem costura a boca da cobra para silenciar as ordens dos antigos aldeões.

Como se percebe, as personagens não se destacam por serem boas ou más: são inerentes a elas, contudo, as marcas de suas formações sociais. Essas marcas conduzem o modo de relação entre protagonistas e personagens secundários. Em muitos dos contos de Marina Colasanti, os protagonistas se desconstroem em relação às normas de conduta sociais. Do mesmo modo, as problemáticas pelas quais passam as personagens não se vinculam diretamente à realidade, pois, os contos de fadas incluem a fantasia no universo da própria narrativa, não se vinculando diretamente a um mundo real $e$ identificável.

Tomando como ponto de partida os contos de Perrault, por exemplo, entre os atributos das personagens, encontramos: "[...] são muito lindas, dóceis e amáveis e lembram as garotas ingênuas e desprotegidas que estão expostas aos perigos do mundo" (MENDES, 2000, p. 124). Além disso, há outros momentos que enaltecem uma função de feminilidade construída socialmente, que se nota, por exemplo, no momento em que, em "Gato de botas", a princesa é enganada pelo Gato ao vê-lo forjado com as roupas do marquês.

Marisa Mendes (2000) evidencia, assim, que as narrativas de origem popular são fortemente influenciadas pela presença de prêmios e castigos para as boas e más ações das personagens. Em alguns contos de Perrault, por exemplo, percebe-se a presença de prêmios e castigos especiais às mulheres - dessa maneira, "[...] mostram o modo como o sexo feminino é manipulado na sociedade patriarcal" (MENDES, 2000, p. 94). Analisando a ação das personagens femininas em Colasanti, Regina Michelli afirma:

A ação das personagens femininas é geralmente marcada pela transcendência, pelo contato com o sagrado, entendendo-se 0 sentido original deste vocábulo, saccer, ligado à bendição e à maldição. São figuras que sofrem o fado, mas têm a capacidade graças a um poder na esfera do maravilhoso - de modificá-lo, prerrogativa das fadas, descendentes das Moiras gregas, das Parcas latinas, das grandes deusas celtas. Trazem os cabelos soltos ao vento, símbolo de sua liberdade vital e autonomia, e uma jóia fria e brilhante no tornozelo, marca de distinção e profunda ligação com a natureza, em sua pureza pagã. São soberanas, ainda que não pareçam. (MICHELLI, 2010, p. 84).

O feminino, nos contos analisados, é revelador das marcas do patriarcado na constituição do feminino, mas, também, valorizam ações de resistência observadas ao longo da história da humanidade. Colasanti traz à tona cenários que nos permitem perceber que a busca do cerceamento da mulher sempre esteve presente, mas que, do mesmo modo, sempre houve enfrentamento, mesmo que de modo muito sutil.

\section{Considerações Finais}

Marina Colasanti revela, entre as temáticas presentes em seus contos, o feminino. Este é evidenciado por meio de uma linguagem bastante próxima da oralidade, e guardando algumas características importantes dos contos maravilhosos, como a ausência de demarcação de tempo e espaço; são contos com poucos personagens; há falas curtas e pouca interação entre as personagens; não há especificação do gênero em nenhum dos narradores; há pouca participação de personagens secundários. Em termos de conteúdo, mantém-se um problema existencial ao redor do qual a diegese é constituída e o amadurecimento vivenciado pelas protagonistas ao longo do conto.

As marcas da interdiscursividade, por sua vez, evidenciam que, ao elaborar contos de fadas em uma época em que, como defendeu Benjamin (1994), já não é possível dar conselhos, Colasanti também reelabora o modo narrativo em questão: as personagens solucionam, elas próprias, seus dilemas, e os problemas sociais impactam fortemente no modo como as personagens atuam nas narrativas. Em Colasanti, então, o protagonismo da mulher é ativo, enquanto que na maior parte dos contos de fadas tradicionais, mesmo quando a mulher é a protagonista da narrativa, a solução dos dilemas vivenciados é sempre ofertada por alguém externo. 
Em "A primeira só", é possível perceber a atuação do discurso patriarcal no momento em que o pai, toma, ele próprio, a iniciativa de fazer a filha feliz. A marca do discurso patriarcal está bastante presente, também, nos contos tradicionais. O que torna os contos de Colasanti transgressores, então, é o fato de que a tentativa de interferência na subjetividade feminina irá provocar efeito contrário ao esperado: a busca para tirar a filha da tristeza culmina na paixão dela por sua própria imagem, em um diálogo com o mito de Narciso. Devido a essa paixão, sua filha se atira no lago. Do mesmo modo, em "São os cabelos das mulheres", há o predomínio de um discurso dominante. A diferença é que a questão do cabelo longo, algo socialmente atribuído à mulher, parece impactar em questões relativas a toda a sociedade, não mais só a ela, em específico. Assim, as ações de uma única mulher - tirar o xale no final da narrativa -, impacta na ação das próximas, que, a exemplo da primeira, se veem motivadas a retirar os seus.

Ressalta-se, assim, que os contos analisados evidenciam a desconstrução, no plano do literário, de valores patriarcais ainda vigentes, e a necessidade de um olhar crítico para tais questões. O suicídio, no primeiro conto, e a liberdade representada pelos cabelos, no segundo, revelam o contato íntimo com o sagrado partilhado nos mitos.

\section{Referências}

BENJAMIN, Walter. O Narrador - considerações sobre a obra de Nicolai Leskov. In: Magia e Técnica, Arte e Política. Obras Escolhidas I. Trad. Sérgio Paulo Rouanet. São Paulo: Brasiliense, 1994.

BETTELHEIM, Bruno. A psicanálise dos contos de fadas. 8. ed. Trad. Arlete Caetano. Rio de Janeiro: Paz e Terra, 1980.

COELHO, Nelly Novaes. O conto de fadas. São Paulo: Ática, 1987.

COLASANTI, Marina. Mais de 100 histórias maravilhosas. Ilustrações de Marina Colasanti. São Paulo: Global, 2015.

FEDERICI, Silvia. Calibã e a Bruxa: mulheres, corpo e acumulação primitiva. Trad. Coletivo Sycorax. São Paulo: Elefante, 2004.

HANISCH, Carol. O Pessoal é Político. Art. Nova York, 1969. Tradução livre. Disponível em: https://we.riseup.net/assets/190219/O+Pessoal\%2B\%
C3\%A9\%2BPol\%C3\%ADtico.pdf. Acesso em: 18 maio 2020.

HOLLANDA, Heloísa Buarque de (Org.). Tendências e impasses: o feminismo como crítica da cultura. Rio de Janeiro: Rocco, 1994.

LAJOLO, Marisa; ZILBERMAN, Regina. Literatura infantil brasileira. História e Histórias. 6. ed. São Paulo: Ática, 2007.

LAURETIS, Teresa de. A tecnologia do gênero. Tradução de Suzana Funck. In: HOLLANDA, Heloisa (Org.). Tendências e impasses: o feminismo como crítica da cultura. Rio de Janeiro: Rocco, 1994. p. 206242.

LIEBEL, Silvia. Demonização da mulher: a construção do discurso misógino no Malleus Maleficarum. Monografia. (curso de História) - Universidade Federal do Paraná, curso de História, setor de Ciências Humanas, Letras e Artes da UFPR. Curitiba, 2004. Disponível em: <http://www.historia.ufpr.br/monografias/2003/silvia_li ebel.pdf>. Acesso em: 3 set. 2017.

MEDEIROS, Nilda Maria. A enunciação poética nos contos de Marina Colasanti. 2009. 204 f. Dissertação (Mestrado em Estudos Literários) - Universidade Estadual Paulista, Faculdade de Ciências e Letras, Campus de Araraquara. Disponível em: $<$ http://wwws.fclar.unesp.br/agenda-

pos/estudos_literarios/1721.pdf>. Acesso em: 27 ago. 2017.

MENDES, Marisa B. T. Em busca dos contos perdidos. O significado das funções femininas nos contos de Perrault. São Paulo: UNESP; Imprensa Oficial do Estado, 2000.

MICHELLI, Regina. Marina Colasanti: A figura feminina no cenário do maravilhoso. Revista Augustus; Rio de Janeiro. Ano 15. N. 30. Agosto de 2010. Disponível em: $<$ http://apl.unisuam.edu.br/augustus/images/edicao30/p df/rev_aug_30_art09.pdf >. Acesso em: 2 set. 2017.

PROPP, Vladimir. Morfologia do Conto Maravilhoso. Trad. Jasna Paravich Sarhan. Rio de Janeiro: Forense Universitária, 1984.

ZIPES, Jack David. Fairy tales and the art of subversion: the classical genre for children and the process of civilization. 2. ed. New York: Routledge, 2006

BARBOSA DA SILVA CORDEIRO, MAISA; RIBEIRO RODRIGUES, RAUER. Literatura juvenil e crítica feminista: emancipação nos contos de fada de Marina Colasanti. Signo, Santa Cruz do Sul, v. 45, n. 84, p. 47-59, dez. 2020. ISSN 1982-2014. Disponível em: <https://online.unisc.br/seer/index.php/signo/article/view/153 85. doi:https://doi.org/10.17058/signo.v45i84.15385. 